\title{
Effects of anaerobic exercise and detraining on the caspase-3 expression of rat ventricular cardiomyocyte
}

\author{
Minarma Siagian, ${ }^{1}$ Maria Lousiana, ${ }^{1}$ Dewi I.S. Santoso, ${ }^{1}$ Sutjahjo Endardjo ${ }^{2}$ \\ ${ }^{1}$ Department of Physiology, Faculty of Medicine, Universitas Indonesia, Jakarta, Indonesia \\ 2 Department of Pathology, Faculty of Medicine, Universitas Indonesia, Jakarta, Indonesia
}

\section{ABSTRAK}

Latar belakang: Latihan fisik anaerobik adalah latihan fisik yang dilakukan dalam waktu singkat dengan intensitas tinggi. Hal ini dapat merangsang apoptosis pada kardiomiosit ventrikel kiri. Penelitian ini bertujuan untuk menganalisis apoptosis kardiomiosit pasca latihan serta pasca henti latih latihan fisik anaerobik.

Metode: Penelitian ini menggunakan 32 ekor tikus Wistar Ratus Novergicus dengan berat badan antara 250-350 gram (usia 8-10 minggu), dibagi dalam 8 kelompok dengan $n=4$ pada tiap kelompok dan diberi latihan fisik anaerobik selama 4 dan 12 minggu (kelompok Exc-4, Exc-12) dan latihan anaerobik diikuti empat minggu henti latih (Exc-4-D, Exc-12-D). Kelompok pembanding hanya diobservasi dalam periode yang sama (kelompok Ctl-4, Ctl-12, Ctl-4-D, Ctl-12-D). Pada akhir pengamatan tikus dieutanasia dan jantung diambil untuk pemeriksaan ekspresi caspase-3 sebagai indikator proses apoptosis menggunakan pulasan imunohistokimia. Data dianalisis dengan uji ANOVA.

Hasil: Terjadi peningkatan ekspresi caspase-3 pada kelompok Exc-4 (72,03\%) dibanding Ctl-4 (27,22\%), $(p<0,001)$; dan Exc$12(79,30 \%)$ dibanding Ctl-12 (30,53\%) ( $p=0,027)$. Proses henti latih menurunkan ekspresi caspase-3 secara signifikan (31,12\% pada Exc-4-D dan 30,44\% pada Exc-12-D).

Kesimpulan: Latihan fisik anerobik dapat meningkatkan apoptosis pada kardiomiosit jantung tikus ditandai dengan peningkatan ekspresi caspase-3. Henti latih dapat memperbaiki kondisi jantung yang ditandai dengan penurunan ekspresi caspase-3.

ABSTRACT

Background: Anaerobic physical exercise is a high intensity physical exercise performed in a short time. This exercise can stimulate apoptosis in left ventricular cardiomyocytes. The aim of this study is to analyze the apoptosis of cardiomyocytes after anaerobic exercise and detraining.

Methods: Thirty two wistar rats Ratus Novergicus 250-350 grams (8-10 weeks old) were divided into the following groups $(\mathrm{n}=4)$ and given naerobic physical exercise four and 12 weeks (group Exc-4, Exc-12) and anaerobic exercise followed by four weeks of detraining (Exc-4-D, Exc-12-D). The control groups were only observed in the same period (group CTL-4, CTL-12, CTL-4-D, CTL-12-D). At the end of observation, the rats were sacrificed and examination of the expression of caspase-3 as an indicator of apoptosis was done using immunohistochemical staining. Data were analyzed with ANOVA test.

Results: An increase in expression of caspase- 3 in the group Exc-4 (72.03\%) compared to the CTL-4 $(27.22 \%),(p<0,001)$; and Exc-12 (79.30\%) compared to the CTL-12 (30.53\%) (p $=0.027$ ). Detraining process showed a significant decline Capase-3 expression $(31.12 \%$ in exc-4-D and $30.44 \%$ in the exc-12-D).

Conclusion: Anaerobic physical exercise can increase apoptosis in rat left ventricle cardiomyocyte characterized by increased expression of caspase-3. Detraining can improve heart condition characterized by decreased expression of caspase-3.

Keywords: anaerobic exercise, cardiomyocytes left ventricle, caspase-3, detraining pISSN: 0853-1773 • eISSN: 2252-8083 • http://dx.doi.org/10.13181/mji.v24i2.1220 • Med J Indones. 2015;24:84-90 - Received 17 Mar 2015 • Accepted 3 Jul 2015

Correspondence author: Minarma Siagian, lousianasuwarno@gmail.com

Copyright @ 2015 Authors. This is an open access article distributed under the terms of the Creative Commons Attribution-NonCommercialShareAlike 4.0 International License (http://creativecommons.org/licenses/by-nc-sa/4.0/), which permits unrestricted non-commercial use, distribution, and reproduction in any medium, provided the original author and source are properly cited. 
Physical exercise is a series of regular exercise and movement consciously planned by people to improve the functional capacities and then improving health status. ${ }^{1}$ In addition to improving health, physical exercise is also beneficial for treatment or prevention of disease. ${ }^{2}$ Physical exercise becomes important in everyday life because accordingly about $12 \%$ of cardiovascular diseases are due to lack of physical activity. ${ }^{2}$

According to its type and intensity, physical exercise will give positive influence on the physiology of the heart, such as increased myocardial oxygen supply and myocardial contractility. In addition, some morphological changes can also be observed, such as an increase in leftand right ventricle the diameter, left atrial dimension, cardiac mass and thickening of the left ventricular wall. ${ }^{3,4}$ These changes are followed by the change in ejection fraction which is characteristic of cardiac physiology in athletes (athlete's heart). ${ }^{3-5}$

Some studies showed the risk of cardiac arrhythmias in athlete's heart, especially cardiac arrest caused by pathological changes as a result of an increase in wall stress, decreased elasticity, impaired left ventricular diastolic relaxation, increased left ventricular end-diastolic volume and decreased contractility. Whereas the function of the heart and blood vessels constantly is challenged to meet the metabolic needs of skeletal muscle in high intensity physical exercise ${ }^{6-8}$ Anaerobic exercise might also a trigger of myocardial infarction as approximately 4\%$20 \%$ of myocardial infarction (MCI) is reported to occur immediately after exertion. ${ }^{2}$ Evidence of increased sudden cardiac death and myocardial infarction have been reported, with the incidence in adults being higher than young people. The incidence is $2.62 / 100,000$ cases in men and $1.07 / 100,000$ in women athletes per year. Risk of sudden cardiac death was also 2.5 times higher in athletes than those who do not exercise. ${ }^{9,10}$

High intensity physical exercise causes an increase in myocardial oxygen demand and requires more oxygen supply, which can induce cardiac hypertrophy both physiological and pathological. ${ }^{11}$

Animal study in rat showed that physical exercise for four days, 10 days, and 13 weeks are associated with chronic excessive pressure load on the heart that stimulates apoptosis. ${ }^{12}$
The occurence of cardiomyocyte apoptosis is associated with the stretching of cardiomyocytes and increased concentrations of neurohormonal factors, such as angiotensin II and natriuretic factor. Stretching is the mechanical factor that plays a role in apoptosis of cardiomyocytes and causes morphological changes in the later phases of the stages of apoptosis. ${ }^{13}$

Barauna et $\mathrm{al}^{14}$ reported that resistant exercise for four weeks induced cardiac hypertrophy without changes in heart function. The opposite is reported by Daustar et al $^{15}$ that training for four weeks did not induce excessive damage to the heart, because the level of apoptosis and infarct size did not change. Siu et $\mathrm{al}^{16}$ stated that exercise above 12 weeks did not show increased expression of Bax and Bcl-2 (apoptosis induction attenuated). In contrast, Kwak et $\mathrm{al}^{17}$ reported that 12-weeks exercise significantly increased apoptosis in the left ventricle.

Apoptotic stimulus is expected to decrease with the cessation of exercise or detraining after high intensity exercise. Detraining train for four weeks can reduce the wall stress of the left ventricle which causes a decrease in adaptation and function of left ventricular myoctes contractility back just like before getting physical exercise. ${ }^{18}$ High intensity exercise has the potential to cause death in athletes, due to the occurrence of pathological cardiac hypertrophy. Whether the cessation of exercise will reduce the risk of death is still questionable. ${ }^{12}$

In this study, we wanted to verify the hypothesis that physical anaerobic exercise will increase apoptosis and detraining will decrease the level of expression of apoptotic proteins in cardiac muscle cells.

\section{METHODS}

This was an experimental study conducted in the Department of Physiology and Department of Pathology, Faculty of Medicine, Universitas Indonesia, Jakarta, Indonesia from May to July 2014. Wistar rats (Rattus norvegicus) aged between 8-10 weeks with body weights ranging between 250-350 grams were used. Animal were alocated to four groups of anaerobic exercise: four and 12 weeks anaerobic exercise (group Exc-4, Exc-12) and four and 12 weeks exercise followed 
by four weeks of detraining (group Exc-4-D and Exc-12-D). In addition, we also allocated four control groups for each exercise groups, namely Ctl-4, Ctl-12, Ctl-4-D, and Ctl-12-D, respectively. The control groups were not subjected to exercise, but only observed for the same length of period.

Anaerobic physical exercise was done with animal treadmill at 35 meter/min speed, for 15 minutes (with 90 seconds break every five minutes of exercise).

At the end of exercise or detraining period, the animals were sacrificed by decapitation, and the heart was collected and paraffin blocks of left ventricle were prepared with immunohistochemical staining of caspase-3 as indicator of apoptosis.

Expressions of caspase- 3 were detected according to standard protocol from the Department of Pathological Anatomy, Faculty of Medicine Universitas Indonesia (Starr Trek HRP-DAB or Horseradish Peroxidase Diaminobenzidine method). The primary antibody used was anticaspase-3 antibody (Abcam Ab4051) with of the optimization 1:100. Primary antibody incubation with PBS 0,1\% + tween $20+5 \%$ donor horse serum and carried out overnight.

Photos of immunohistochemistry (IHC) with 2048x1536 pixels were taken from light microscope Leica DM500 with Leica ICC50 HD camera (magnification 40x). Five different visual fields were taken at random. The data measured were the percentage of caspase-3 expression area counted using Image J program.

Data analysis was done by using SPSS 17. Normality of caspase-3 expression was tested by Saphiro-Wilk method. Comparison among groups was done by one-way ANOVA test, followed by the least significant different (LSD) as post hoc analysis. The protocol of this study has been approved by the Research Ethics Committee of the Faculty of Medicine, Universitas Indonesia (No. 153/PT02.FK/ETIK/2011).

\section{RESULTS}

Positive immunohistochemical results of caspase-3 expression were different in each group as shown in Figure 1. Increase in the

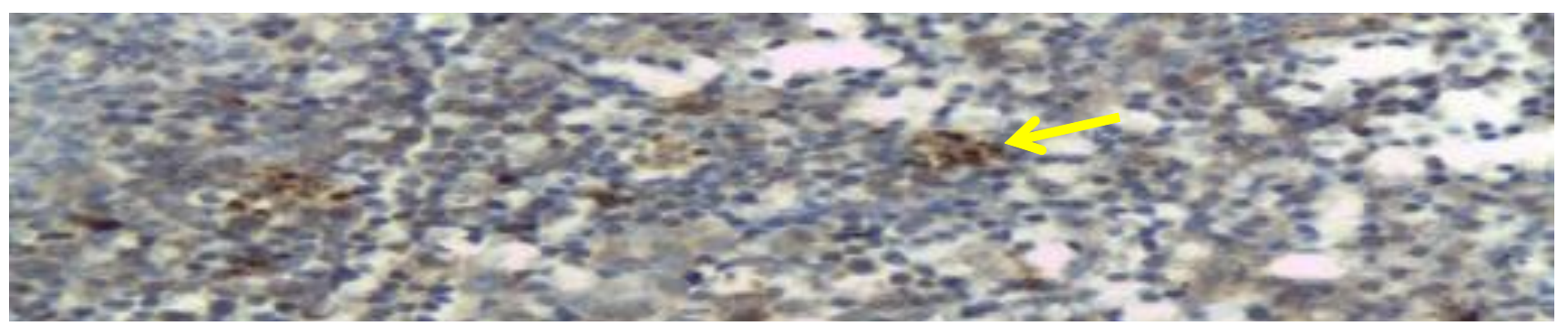

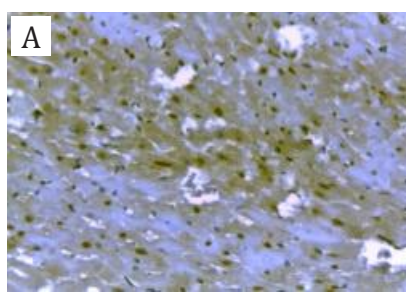
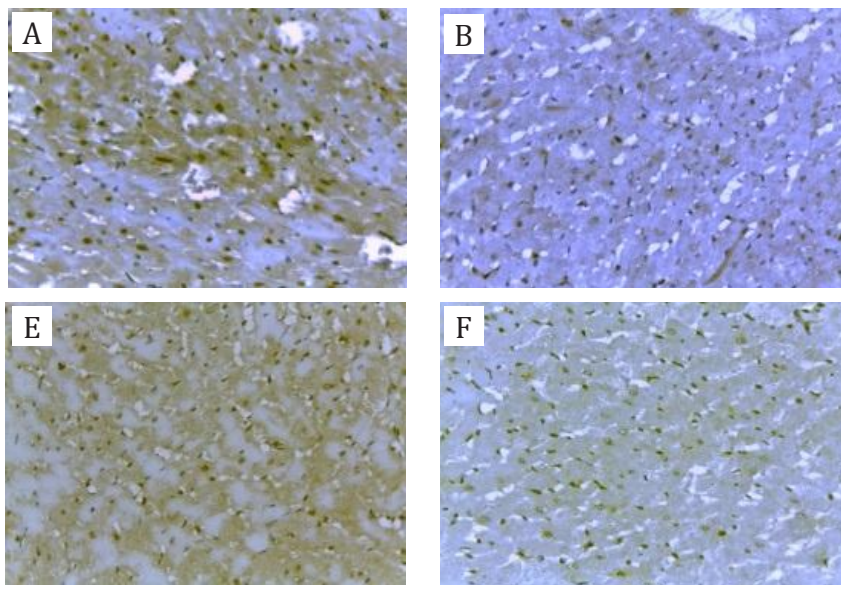
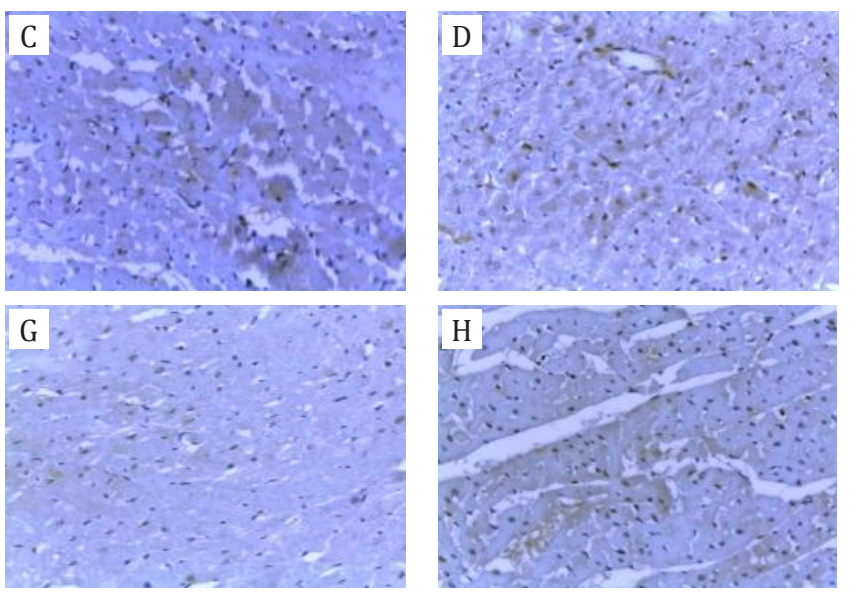

Figure 1. Increase in the percentage area of the expression of caspase-3 (brown in the cytoplasm of rat cardiac left ventricular cardiomyocytes) in: A. Exc-4; B. Exc-4-D; E. Exc-12, and F. Exc-12-D. There is a decrease in the percentage area of caspase-3 expression in: C. Ctl-4 and D. Ctl-4-D , G. Ctl-12 and H. Ctl-12-D. Positive expression of caspase-3 at human tonsillar tissue (yellow arrow). 
percentage of the expression of caspase-3 (brown in the cytoplasm of rat cardiac left ventricular cardiomyocytes) is seen in the in group of anaerobic exercise and detraining. The percentage area of caspase- 3 expression in control groups were lower than those of exercise groups.

Figure 2 showed caspase- 3 expression in the groups of anaerobic exercise and detraining as well as in the control groups. Four weeks anaerobic exercise was associated with significant increase of caspase-3 expression compared to control group, with an average. While the difference between control and detraining group was only 8.91\%. Between Exc-12 difference of $44.81 \%$ the Ctl-12 groups, we obtained an average difference of $48.77 \% \quad(p<0,001)$. The smaller increase (10.95\%) was also observed in the group of Ctl-12 versus Exc-12-D. Further data analysis showed no significant difference between the Ctl-4 and Ctl$12(\mathrm{p}=0.310)$ with a mean difference of $-3.31 \%$. Likewise, between the Exc-4-D and Exc-12-D groups $(p=0.835)$ with an average difference of $0.69 \%$.

\section{DISCUSSION}

Anaerobic exercise for 4 and 12 weeks showed significantly increase in apoptosis as indicated by significant increase of caspase- 3 expression. In contrast, detraining process was associated with the decrease of caspase- 3 expression approaching the control values of the corresponding groups.

Figure 2 showed the average percentage of the increase in caspase-3-positive following 4 and 12 weeks of anaerobic exercise. Different exercise procedure in the study of Jin et $\mathrm{al}^{12}$ showed no increase in the expression of apoptosis after physical exercise for 4 days, 10 days and 13 weeks. They used treadmill running exercise of $36 \mathrm{~m} / \mathrm{min}$ for $60 \mathrm{~min} / \mathrm{d}$ (5 days/ week) in mice aged 6-8 weeks. The increase in the average percent positive caspase- 3 in the anaerobic physical exercise groups four and 12 weeks indicates that cardiomyocyte apoptosis may play an important role in the early stages of cardiac adaptation to pathological burden but not for physiological loads. High intensity physical exercise requires long-term adaptation to work load as well as to high demand. Increased left ventricular volume during exercise requires a high blood flow and left ventricular hypertrophy which can lead to high systemic arterial pressure which force the heart to make prolonged adjustments. ${ }^{12,19}$ Myocardial apoptosis is expected to determine the initial stages of cardiac adaptation to

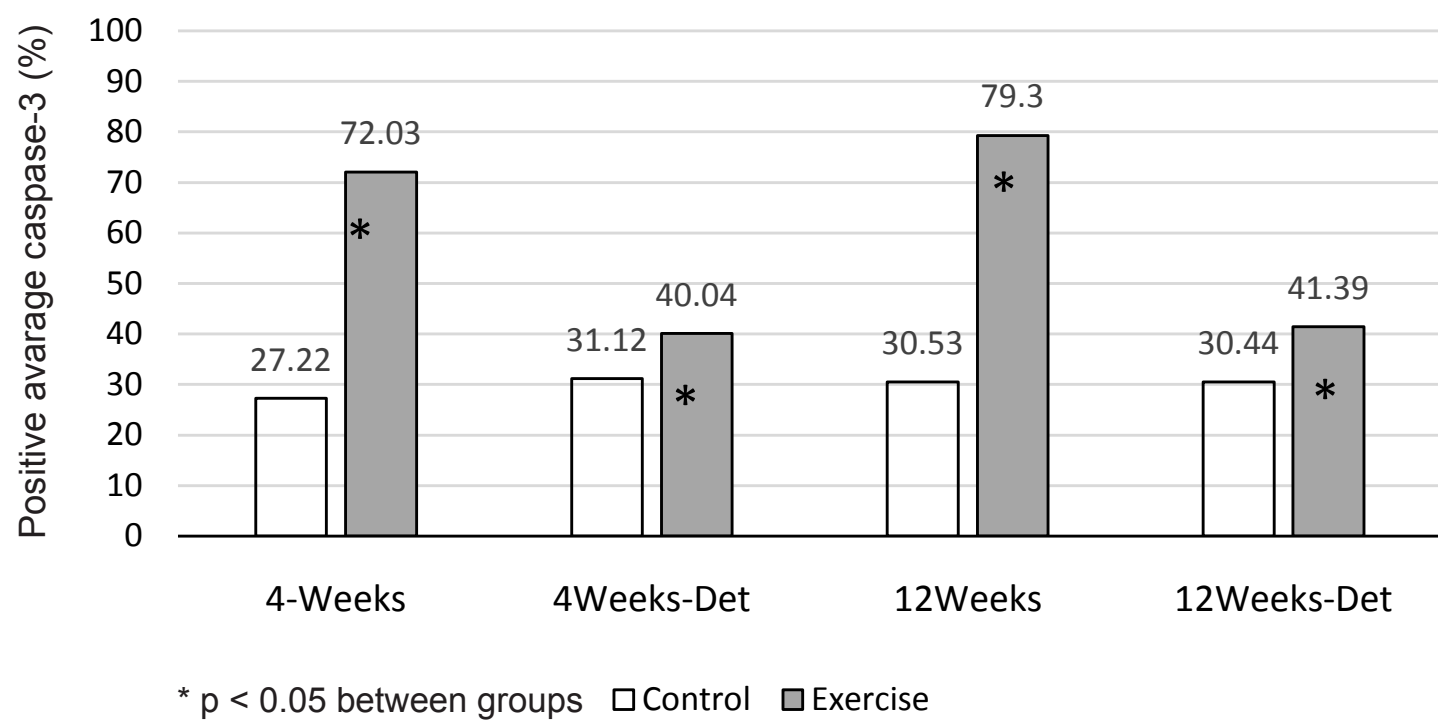

Figure 2. Comparison of average percentage of caspase-3 expression between groups of anaerobic exercise and the corresponding control groups 
physiological and pathological burden. Influence of physical exercise on the heart vary according to differences in the species, age, sex, and duration and intensity of exercise. ${ }^{12}$ Duration and intensity of training are the important factors that promote adaptation of cardiomyosite. $^{20}$

Teiger et $\mathrm{al}^{21}$ founds that apoptosis occurs in the first seven days after excessive pressure, with a peak at four days, whereas cardiac growth continues for more than 30 days. The increase of caspase-3 expression indicated that cardiac adaptation to pressure overload is mediated by cardiomyocyte apoptosis. ${ }^{12}$ Caspase- 3 is an executor of apoptosis pathway as a mediator between mitochondrial and death receptor apoptotic pathway. Stretching cardiomyocyte and increased left ventricular wall stress can trigger death receptor as characterized by the increased expression of Fas protein. ${ }^{22}$

High-intensity anaerobic physical exercise causes an increase of end-diastolic pressure due to excessive load and can lead to wall stress, which further stimulate sarcomer replication, fiber elongation, and enlargement of cardiac chamber or eccentric hypertrophy. ${ }^{13}$ Acute increase of wall stress may lead to replication of sarcomeres, concentric wall thickening and hypertrophy associated with significant increase of left ventricular mass. ${ }^{14}$ According to some literatures, the excessive pressure burden can also stimulate apoptosis and cause excessive expression of growth factors, increased collagen deposits and deletion of mitochondrial deoxyribose nucleic acid (mtDNA), ${ }^{2,11,21,23}$ Cell growth signal produces conflicting genetic request and trigger the apoptotic response. Continuous growth stimulation can induce cardiomyocyte hypertrophy as a result of loss of intracellular survival signals that normally suppress the apoptosis. ${ }^{24}$

Regarding the influence of detraining, Pelliccia et $\mathrm{al}^{25}$ reported that ventricular adaptation and myocardial contractility returned to normal conditions Teiger et $\mathrm{al}^{21}$ after detraining. ${ }^{25}$ Detraining can reduce changes in cardiacfunction, fibrosis and susceptibility to arrhythmia. ${ }^{13,18}$ However, the size of cardiac chamber and left ventricular mass may remain elevated despite reduction of dilation by detraining. ${ }^{13}$ Decrease cardiac chamber is hindered due to the expansion of interstitial collagen matrix that occur during cardiac remodelling in response to chronic stretching of the pericardium. Normalization of cardiac morphology in athletes occurred long after detraining as indicated by the reversibility of arrhythmia after cessation of exercise. ${ }^{13,26}$ In mice, regression occurs even after only two weeks of detraining train which indicates that cardiac mass in mice returned to basal state after about 21 days of detraining. ${ }^{27}$

According to Liu et $\mathrm{a}^{28}$ age may contribute to the loss of more than $30 \%$ of cardiac myocytes without heart disease, and can lead to myocardial dysfunction or heart failure. ${ }^{29}$ In addition, These authors also reported that the expression of protein Bcl-2 and Bax increased in the heart of old Fischer-344 rats under physiological conditions. ${ }^{28}$ While other author reported age-related increase in cardiomyocyte apoptosis without significant changes in proteins Bax and Bcl-2. ${ }^{30}$ Progressive apoptosis of left and right ventricles of male rats occurred at 6,16, and 24 months of age, while cytochrome $\mathrm{C}$ was significantly increased at 16 and 24 months compared to six months of age. So, the study on mice aged 4, 8, 12 and 16 weeks has not demonstrated quite high activity of caspase-3 protein.

Stages of myocyte loss may be associated with cell death that continuously and constantly occur throughout life. ${ }^{26}$ In humans and animals, cardiac aging is characterized by a decrease in the number of myocytes with reactive hypertrophy and fibrosis of the remaining cells. ${ }^{30}$ Increased apoptosis may be a consequence of a decrease in mitochondrial membrane stability and transition pore formation due to increasing age, which leads to the release of cytochrome into the cytosol, and ultimately to activation of caspase- 3 and caspase-9. ${ }^{30}$ The loss of cardiac myocytes do not always lead to a reduction in cardiac mass. Aging process may cause an increase in cardiac connective tissue, stiffness/thickness of the wall, and loss of elasticity of the heart due to the loss or decrease in the number of myocytes. This will ultimately affect the contractility of the heart muscle. ${ }^{30}$

In conclusion, an increase in expression of caspase-3 after physical anaerobic exercise of 
4 and 12 weeks showed that anaerobic physical exercise causes an increase in the cardiomyocyte apoptosis. Increased intensity and duration of anaerobic exercise may have harmful effect on the heart. Decreased expression of caspase-3 after detraining indicates that detraining is important for the recovery of cardiac dysfunction.

\section{Acknowledgments}

The authors are grateful to beasiswa pendidikan pasca-sarjana Direktorat Jenderal Pendidikan Tinggi (BPPS DIKTI) and Sekolah Tinggi Ilmu Kesehatan Sint Carolus (STIK Sint Carolus), which have funded this study.

\section{Conflict of interest}

The authors affirm no conflict of interest in this study.

\section{REFERENCES}

1. Giriwijoyo S, Sidik DZ. Ilmu faal olahraga (fisiologi olahraga): fungsi tubuh manusia pada olahraga kesehatan dan prestasi. Bandung: Remaja Rosdakarya; 2012. Indonesian.

2. Bowles DK, Laughlin MH. Mechanism of beneficial effects of physical activity on atherosclerosis and coronary heart disease. J Appl Physiol (1985). 2011;111(1):308-10.

3. Boreham C, Budgett R, Carbon R, Nicholas D, Franco A, Godfrey R, et al. The physiology of training. Philadelphia: Elselvier; 2006.

4. McArdle WD, Katch FL, Katch KL. Exercise physiology: nutrition, energy and human performance. 4th ed. Philadelphia: Lippincott William \& Wilkins; 2011.

5. Haykowsky MJ. Left ventricular remodelling and the athlete's heart: time to revisit the Morganroth hypothesis. J Physiol. 2011;589(Pt 24):5915.

6. Elmore S. Apoptosis: a review of programmed cell death. Toxicol Pathol. 2007;35(4):495-516.

7. Gielen S, Schuler G, Adams V. Cardiovascular effect of exercise training molecular mechanism. Circulation. 2010;122(12):1221-38.

8. Thompson PD, Franklin BA, Balady GJ, Blair SN, Corrado D, Estes NA, et al. Exercise and acute cardiovascular events placing the risk into perspective: a scientific statement from the American Heart Association Council on Nutrition, Physical Activity, and Metabolism and the Council on Clinical Cardiology. Circulation. 2007;115(17):2358-68.

9. Dickson EW, Hogrefe CP, Ludwig PS, Ackermann LW, Stoll LL, Denning GM. Exercise enhances myocardial ischemic tolerance via an opioid receptor-dependent mechanism. Am J Physiol Heart Circ Physiol. 2008;294(1):402-8.

10. Kavazis AN, Mc Clung JM, Hood DA, Powers SK. Exercise induces a cardiac mitochondrial phenotype that resists apoptotic stimuli. Am J Pysiol Heart Circ. 2008;294(2);H928-35.
11. Ellison GM, Waring CD, Vicinanza C, Torella D. Physiological cardiac remodelling in response to endurance exercise training: cellular and molecular mechanisms. Heart. 2012:98(1):5-10.

12. Jin H, Yang R, Li W, Lu H, Ryan AM, Ogasawara AK, et al. Effect of exercise training on cardiac function, gene expression, and apoptosis in rats. Am J Physiol Heart Circ Physiol. 2000;279(6):H2994-H3002.

13. Dispersyn GD, Borgers M. Apoptosis in the heart: about programmed cell death and survival. News Physiol Sci. 2001;16:Barauna VG, Rosa KT, Irigoyen MC, de Oliveira EM. Effects of resistance training on ventricular function and hypertrophy in a rat model. Clin Med Res. 2007;5(2):114-20.

14. Daustar Y, Soufi FG, Jafary A, Saber MM, Ghiassie R. Role of four-week resistance exercise in preserving the heart against ischaemia-reperfusion-induced injury. Cardiovasc J Afr. 2012;23(8):451-5.

15. Siu PM, Bryner RW, Martyn JK, Always SE. Apoptotic adaptations from exercise training in skeletal and cardiac muscles. FASEB J. 2004;18(10):1150-2.

16. Kwak HB, Song W, Lawler JM. Exercise training attenuates age-induced elevation in Bax/Bcl-2 ratio, apoptosis, and remodeling in the rat heart. FASEB J.2006;20:791e3.

17. Carneiro-Júnior MA, Pelúzio $\mathrm{MC}$, Silva $\mathrm{CH}$, Amorim PR, Silva KA, Souza MO, et al. Exercise training and detraining modify the morphological and mechanical properties of single cardiac myocytes obtained from spontaneosly hypertensive rats. Braz J Med Biol Res. 2010;43(11):1042-6.

18. Rhoades R, Tanner G. Medical physiology. 2nd ed. Philadelphia: Lippincott Williams \& Wilkins; 2003.

19. Ahmadiasl N, Soufi FG, Alipour M, Bonyadi M, Sheikhzadeh F, Vatankhah A, et al. Effects of age increment and 36-week exercise training on antioxidant enzymes and apoptosis in rat heart tissue. J Sport Sci Med. 2007;6(2):243-9.

20. Teiger E, Than VD, Richard L, Wisnewsky C, Tea BS, Gaboury L, et al. Apoptosis in pressure overloadinduced heart hypertrophy in the rat. J Clin Invest. 1996;97(12):2891-7.

21. Moorjani N, Ahmad M, Catarino P, Brittin R, Trabzuni D, Al-Mohanna F, et al. Activation of apoptotic caspase cascade during the transition to pressure overload-induced heart failure. J Am Coll Cardiol. 2006;48(7):1451-8.

22. Huang CC, Lin TJ, Chen CC, Lin WT. Endurance training accelerates exhaustive exercise-induced mitochondrial DNA deletion and apoptosis of left ventricle myocardium in rats. Eur J Appl Physiol. 2009;107(6):697-706.

23. Fortuño MA, Ravassa S, Fortuño A, Zalba G, Diez J. Cardiomyocyte apoptotic cell death in arterial hypertension: mechanisms and potential management. Hypertension. 2001;38(6):1406-12.

24. Pelliccia A, Maron BJ, De Luca R, Di Paolo FM, Spataro A, Culasso F. Remodeling of left ventricular hypertrophy in elite athletes after long-term deconditioning. Circulation. 2002;105(8):944-9.

25. Mallat Z, Fornes P, Costagliola R, Esposito B, Belmin $\mathrm{J}$, Lecomete D, et al. Age and gender effects on cardiomyocyte apoptosis in the normal human heart. J Gerontol A Biol Sci Med Sci. 2001;56(11):M719-23. 
26. Bocalini D, Carvalho E, Mello de Sousa A, Levy R, Tucci P. Exercise training-induced enhancement in myocardial mechanics is lost after 2 weeks of henti latihin rats. Eur J App Physiol. 2010;109:909-14.

27. Liu M, Zhang $\mathrm{P}$, Chen $\mathrm{M}$, Zhang $\mathrm{W}$, Yu L, Yang XC, et al. Aging might increase myocardial ischemia / reperfusion-induced apoptosis in humans and rats. Age
(Dordr). 2012;34(3):621-32.

28. Kajstura J, Cheng W, Sarangarajan R, Li P, Li B, Nitahara $\mathrm{JA}$, et al. Necrotic and apoptotic myocyte cell death in the aging heart of Fischer 344 rats. Am J Physiol. 1996;271(3 Pt 2):H1215-28.

29. Kwak HB. Effects of aging and exercise training on apoptosis in the heart. J Exerc Rehabil. 2013;9(2):212-9. 